Discussion Paper 65

Institute for Empirical Macroeconomics

Federal Reserve Bank of Minneapolis

250 Marquette Avenue

Minneapolis, Minnesota 55480-0291

May 1992

\title{
DYNAMICS OF THE TRADE BALANCE AND THE TERMS OF TRADE: THE J-CURVE REVISITED
}

\author{
David Backus* \\ Stern School of Business \\ New York University
}

\author{
Patrick Kehoe* \\ University of Minnesota and \\ Federal Reserve Bank of Minneapolis
}

Finn Kydland*

Carnegie Mellon University

\begin{abstract}
We provide a new interpretation of the statistical relation between the trade balance and the terms of trade. This relation includes the J-curve, the tendency for trade balances to be negatively correlated with contemporaneous movements in the terms of trade, positively correlated with lagged movements. We document this property in international data and show that it arises, as well, in a two-country stochastic growth model. In the model trade dynamics result, in large part, from fluctuations in investment. A favorable productivity shock in the domestic economy leads to an increase in domestic output, a decrease in its relative price,. and a rise in the terms of trade. The increase in domestic productivity also leads to a temporary investment boom. This boom results in an initial trade deficit, followed by future surpluses, and thus a J-curve. We also use the model to provide a new perspective on earlier theories of trade and price dynamics.
\end{abstract}

*We thank the National Science Foundation, the Institute for Empirical Macroeconomics, and the Center for Japan-U.S. Business and Economic Studies faculty fellowship program for financial support. We also thank participants at the Rochester workshop, "International Transmission of Business Cycles," for helpful suggestions at an early stage of this project.

Any opinions, findings, conclusions, or recommendations expressed herein are those of the authors and not necessarily those of the University of Minnesota, the Federal Reserve Bank of Minneapolis, or the Federal Reserve System. 
We provide a new interpretation of one of the central relations in international economics: the relation between the trade balance and the terms of trade. The subject dates back at least to Marshall (1923), and continues to interest policymakers and students of international trade flows. Early theoretical work by Lerner (1944), Marshall (1923), and Robinson (1947) approached the relation between trade and relative prices using static demand theory; they suggested that its sign depends on the magnitude of demand elasticities for imports and exports. Later studies by Harberger (1950) and Laursen and Metzler (1950) emphasized the connection between the trade balance and saving, and thus between saving and the terms of trade. More recently, Obstfeld (1982) and Svensson and Razin (1983) initiated a revival of this approach in which saving is determined by explicit intertemporal optimization. Their work emphasized the interplay between consumption smoothing motives and relative prices. What most of this work has in common is its partial equilibrium perspective, in which exogenous movements in the terms of trade are associated with responses of net exports. The relation between net exports and the terms of trade is thought to be structural, in the sense of being invariant to the source of relative price movements.

Most applied work in this area -- Rose and Yellen (1989) are a notable exception -- introduces dynamic elements to the trade/price relation. Thus Dornbusch and Krugman (1976, p 551) remark: "It has become an accepted fact ... that in many cases the trade balance worsens over the short term in response to a depreciation, responding favorably over time. This reversal of direction of the trade effect -- which is known as the J-curve ... - is ascribed to a slow adjustment of export prices and physical trade flows in contrast with the rapid increase in import prices." We formalize the J-curve using the cross-correlation function between net exports and the terms of trade. We say there is a J-curve if the trade balance is negatively 
correlated with future movements in the terms of trade but positively correlated with past movements. We find this pattern in most of the eleven OECD countries we study.

Our objective is to provide a dynamic general equilibrium interpretation for observed comovements of the terms of trade and the trade balance. Our theoretical structure extends earlier work on trade and price dynamics by Hodrick (1988) and Stockman and Svensson (1987), who develop simple general equilibrium models in which the terms of trade is determined endogenously. In our economy, two countries produce imperfectly substitutable goods with capital and labor, and fluctuations arise from persistent shocks to aggregate productivity. We find that with plausible parameter values the economy gives rise to a J-curve. The dynamic response functions provide some intuition for this property. A favorable productivity shock leads to an increase in domestic output, a decrease in its relative price, and a rise in the terms of trade. The increase in domestic productivity also: leads to a temporary investment boom, as capital is shifted to its most productive location. Primarily because of the large increase in investment, the economy initially experiences a trade deficit, which is followed by surpluses several quarters later.

Our theoretical economy puts earlier theoretical work in a new light. We find, first, that the elasticity of substitution between foreign and domestic goods determines the sign of the correlation between trade and relative prices. This elasticity is different from that emphasized by Marshall, Lerner, and Robinson, but has some of the same motivation. Second, we find, in contrast with both vintages of work on the Harberger-LaursenMetzler effect, that trade dynamics are driven, in large part, by investment. Without capital and investment, our economy does not exhibit either the countercyclical trade or the $\mathrm{J}$-curve we see in the data. If we eliminate 
capital from our economy, the trade balance is simply a reflection of consumption smoothing. In a boom, consumption rises by less than output, leading to a trade surplus and thus procyclical trade. At the same time, the price of domestic goods falls and the terms of trade rises, leading to a positive contemporaneous correlation between these two variables. Over time this correlation decays, producing a tent-shaped cross-correlation function, rather than the asymmetric pattern of correlations we have called the J-curve.

We also find that the general equilibrium perspective is essential. In most earlier work the response of the trade balance to a change in the terms of trade is independent of its source, which is generally not specified. In our general equilibrium setting, the source is critical. An economy with shocks to government spending, for example, rather than productivity, looks in many respects like the economy without capital. The trade balance is procyclical and the cross-correlation function for net exports and the terms of trade is tent-shaped. In this world, an increase in government purchases in the domestic economy raises absorption and drives the trade balance into deficit. Since an increase in government spending favors the domestic good, it raises the price of exports and lowers the terms of trade, thus producing a positive contemporaneous correlation between the trade balance and the terms of trade. Over time this correlation decays, and again produces a tent-shaped cross-correlation function. The difference between the correlations with productivity shocks and those with government spending shocks makes it clear that there is no simple structural relation between these two variables.

These points are developed in the rest of the paper. We start, in Section I, with a description of postwar quarterly data, including the correlation of net exports and the terms of trade, for eleven developed 
countries, In Section II we describe a theoretical economy with two countries. In Section III we discuss the selection of parameter values, and the method we use to compute equilibrium time paths for net exports, the terms of trade, and other variables. In Section IV we turn to the economy's properties, including the correlation between net exports and the terms of trade. Section $\mathrm{V}$ is devoted to two extreme experiments: the economy without capital and investment, and with shocks to government spending alone. We conclude with a few remarks on the usefulness of our theoretical framework for interpreting trade and price movements and other features of international time series data.

\section{Properties of the Data}

We report, in Table 1, some of the salient properties of postwar quarterly trade statistics for eleven developed countries. The data are from the OECD's Quarterly National Accounts and are described more completely in the Appendix. We measure the trade balance, labeled $\mathrm{nx}$ in the table, as the ratio of net exports to output, with both measured in current prices as reported in the national income and product accounts. The terms of trade, labeled $p$, is the ratio of the implicit price deflators for imports and exports -- the relative price of imported goods. Real output is either GNP or GDP in constant prices, and is labeled $y$. Statistics for both $\mathrm{p}$ and $\mathrm{y}$ refer to logarithms. Throughout the paper, statistics refer to Hodrick-Prescott (1980) filtered variables. This filter eliminates the low-frequency movements in the data, leaving us with short-term fluctuations.

We note in Table 1 a number of regularities and irregularities in the behavior of net exports and the terms of trade. First, we report standard deviations of net exports, the terms of trade, and output. There is a fair amount of heterogeneity across countries in the magnitudes of these 
statistics, particularly in the trade variables. The standard deviation of the ratio of net exports to output $(n x)$ ranges from a low of 0.45 percent for the United States to a high of 1.75 for Finland. The standard deviation of the terms of trade varies somewhat less, from 1.96 in Finland to 5.86 in Japan. Work by Alterman (1989) on U.S. trade prices suggests that part of the variability of the terms of trade may result from price indexes that fail to incorporate changes in the quality of goods; we return to this issue later.

Second, both the ratio of net exports to output (nx) and the terms of trade (p) are strongly persistent. The autocorrelation of net exports ranges from 0.29 in Austria to 0.90 in Switzerland, with a median of 0.71 . The autocorrelation of the terms of trade ranges from 0.50 for Austria to 0.88 for Japan and Switzerland, with a median of 0.80 . Austria is an outlier in both cases; we suspect this has something to do with inadequate seasonal adjustment, since seasonal noise would likely raise the standard deviation and lower the autocorrelation.

Third, the contemporaneous correlation between net exports and the terms of trade varies somewhat across countries, but is negative more of ten than not. In Finland, France, Italy, Japan, Switzerland, and the United Kingdom the correlations are less than -0.4. The United States is the only country in which these two variables have a sizable positive contemporaneous correlation. Fourth, we see that net exports is countercyclical in every country in our sample.

Missing from the contemporaneous correlations between net exports and the terms of trade are the complex dynamic relations suggested by earlier work. In Table 2 we report cross-correlation functions for these two variables, for leads and lags up to two years. Numbers on the left side of Table 2 indicate correlations between the terms of trade and lagged net 
exports, numbers on the right the reverse. We see, by and large, that correlations between the terms of trade and past net exports are generally negative, between the terms of trade and future net exports generally positive. We find this a convenient characterization of the dynamic relation between these two variables and refer to it (with perhaps a small amount of violence to the history of the term) as the $\mathrm{J}$-curve.

These correlations may be clearer in Figure 1, a pictorial representation of Table 2 showing, for each country, the correlations between $\mathrm{p}_{\mathrm{t}}$ and $\mathrm{nx} \mathrm{t}_{\mathrm{k}}$. In the neighborhood of $\mathrm{k}=0$, the slope of the crosscorrelation function is uniformly positive. In this sense the correlation between net exports and the terms of trade is greater for lagged terms of trade than contemporaneous. Note, in particular, that the cross-correlation function turns from negative to positive after 2-4 quarters in six of our eleven countries.

In short, we find a number of regularities in the behavior of net exports and the terms of trade for eleven OECD countries. First, the crosscorrelation function between net exports and the terms of trade exhibits a characteristic tilted $\mathbf{J}$ shape, which we label a J-curve. Second, the trade balance is consistently countercyclical. Third, net exports and the terms of trade are highly autocorrelated.

\section{A Theoretical Economy}

We compare these properties of international data to those of a stochastic growth model with two countries, each inhabited by a large number of identical consumers. This world economy is a streamlined two-country version of Kydland and Prescott's (1982) closed economy. In our economy, each country produces a different good with its own technology, and labor is internationally immobile. Fluctuations are driven by stochastic movements in 
productivity and government spending.

Preferences of the representative consumer in each country $i$ are characterized by a utility function of the form

$$
E_{0} \Sigma_{t=0}^{\infty} \beta^{t} U\left(c_{i t}, 1-n_{i t}\right),
$$

where $U(c, 1-n)=\left[c^{\mu}(1-n)^{1-\mu}\right]^{\gamma} / \gamma$ and $c_{i t}$ and $n_{i t}$ are consumption and hours worked, respectively, in country i.

Each country specializes in the production of a single good, labeled "a" for country 1 and "b" for country 2. Each is produced using capital $k$ and labor $\mathrm{n}$ with linear homogeneous production functions $\mathrm{F}$ of the same form. This gives rise to the resource constraints,

$$
\begin{aligned}
& a_{1 t}+a_{2 t}=y_{1 t}=z_{1 t} F\left(k_{1 t}, n_{1 t}\right), \\
& b_{1 t}+b_{2 t}=y_{2 t}=z_{2 t} F\left(k_{2 t}, n_{2 t}\right),
\end{aligned}
$$

in countries 1 and 2 , respectively, with $F(k, n)=k^{\theta} n^{1-\theta}$. The quantity $y_{i t}$ denotes GDP in country $i$, measured in units of the local good, and $a_{i t}$ and $b_{i t}$ denote uses of the two goods in country $i$. The vector $z_{t}=\left(z_{1 t}, z_{2 t}\right)$ is a stochastic shock to productivity whose properties will be described shortly.

Consumption, investment, and government spending in each country are composites of the foreign and domestic goods,

$$
\begin{aligned}
& c_{1 t}+x_{1 t}+g_{1 t}=G\left(a_{1 t}, b_{1 t}\right), \\
& c_{2 t}+x_{2 t}+g_{2 t}=G\left(b_{2 t}, a_{2 t}\right),
\end{aligned}
$$

where $G(a, b)=\left[\omega_{1} a^{-\rho}+\omega_{2} b^{-\rho}\right]^{-1 / \rho}$ is homogeneous of degree one and $\rho \geq-1$. With this function, the elasticity of substitution between foreign and domestic goods is $\sigma=1 /(1+\rho)$. This device for aggregating domestic and foreign goods was suggested by Armington (1969), and is widely used in the empirical trade literature (Whalley, 1985; Deardorff and Stern, 1990). 
Accordingly, we refer to $G$ as an Armington aggregator. The weights $\omega_{i}$ in the aggregator functions $G$ allow us to specify the domestic and foreign content of domestic spending. Government spending is stochastic; we describe its behavior below.

Capital formation follows the time-to-build structure of Kydland and Prescott (1982). As in their economy, it takes $J$ quarters to augment the capital stock. A unit increase in the capital stock $J$ quarters from now involves purchases of $1 / J$ units of the final good for $J$ consecutive quarters. To express this mathematically, let $s_{i t}$ be planned additions to the capital stock of country $i$ in period $t+J$. The capital stocks then evolve according to

$$
\mathrm{k}_{\mathrm{it}+1}=(1-\delta) \mathrm{k}_{\mathrm{it}}+\mathrm{s}_{\mathrm{it}-\mathrm{J}+1} \text {, }
$$

where $\delta$ is the depreciation rate. In period $t$, total expenditure on gross capital formation is

$$
x_{i t}=J^{-1} \Sigma_{j=0}^{j-1} s_{i t-j}
$$

the sum of capital expenditures on all currently active projects. In all experiments but one we set $J=1$, so investment expenditures made in period $t$ increase the stock of capital in period $t+1$.

Finally, the underlying shocks to our economy are independent bivariate autoregressions. The technology shocks follow

$$
z_{t+1}=A z_{t}+\varepsilon_{t+1}^{z}
$$

where $\varepsilon^{\mathbf{Z}}$ is distributed normally and independently over time with variance $\mathrm{V}_{\mathrm{z}}$. The correlation between the technology shocks, $z_{1}$ and $z_{2}$, is determined by the off-diagonal elements of $A$ and $V_{z}$. Similarly, shocks to government spending are governed by

$$
g_{t+1}=B g_{t}+\varepsilon_{t+1}^{g}
$$


where $g_{t}=\left(g_{1 t}, g_{2 t}\right)$ and $\varepsilon^{g}$ is distributed normally with variance $v_{g^{*}}$ Technology shocks $z$ and government spending shocks $g$ are independent.

From these elements we can construct national income and product accounts for each country of our theoretical world economy. GDP in country 1 at date $t$, in units of the domestically produced good, is $y_{1 t}$; the resource constraint expresses this as the sum $a_{1 t}+a_{2 t^{\circ}}$ We tie national output to expenditures as follows. The Armington aggregator expresses absorption, $c_{1 t}+x_{1 t}+g_{1 t}$, as a function of $a_{1 t}$ and $b_{1 t}$. Since the aggregator $G$ is homogeneous of degree one, we have, in equilibrium,

$$
c_{1 t}+x_{1 t}+g_{1 t}=q_{1 t} a_{1 t}+q_{2 t} b_{1 t}
$$

where $\mathrm{q}_{1 \mathrm{t}}$ and $\mathrm{q}_{2 \mathrm{t}}$ are the prices of the two goods at date $t$. From the resource constraint we have

$$
y_{1 t}=\left(c_{1 t}+x_{1 t}+g_{1 t}\right) / q_{1 t}+\left(a_{2 t}-p_{t} b_{1 t}\right)
$$

where $p_{t}=q_{2 t} / q_{1 t}$ is the terms of trade. Thus-output is the sum of absorption and net exports, $a_{2 t}-p_{t} b_{1 t}$. We measure the trade balance in the model as we do in the data, as the ratio of net exports to GDP, with both measured in current prices:

$$
n x_{t}=\left(a_{2 t}-p_{t} b_{1 t}\right) / y_{1 t}
$$

We compute the terms of trade in country 1 from

$$
p_{t}=q_{2 t} / q_{1 t}=\left\{\partial G\left(a_{1 t}, b_{1 t}\right) / \partial b_{1 t}\right\} /\left\{\partial G\left(a_{1 t}, b_{1 t}\right) / \partial a_{1 t}\right\}
$$

the marginal rate of transformation between the two goods in country 1 .

\section{Parameter Values, Steady State, and Computation}

We describe, very briefly, our procedure for selecting parameter values and computing a competitive equilibrium. Both are adapted to the open economy from Kydland and Prescott's (1982) closed economy study; for details, 
see their paper and Backus, Kehoe, and Kydland (1992). As a rule, share parameters for preferences and production are chosen to equate means of ratios in aggregate U.S. time series to analogous ratios in the theoretical economy's steady state. Curvature parameters are selected from existing statistical studies. The parameters of the technology process are estimated from Solow residuals for the United States and an aggregate of European countries. The only new elements are the parameters of the Armington aggregator and the parameters that govern the behavior of shocks to government spending, both of which are described below. Given values for the model's parameters, we compute an equilibrium by solving numerically a quadratic approximation to a social planner's problem.

The most important new parameters in this paper are those of the Armington aggregator G. These parameters govern the elasticity of substitution between foreign and domestic goods and the average ratio of imports to national income. The elasticity of substitution is $\sigma=1 /(1+\rho)$, and there is some uncertainty about what value of this parameter is appropriate. The most reliable studies seem to indicate that for the U.S. the elasticity is between one and two. For Japan and an aggregate of European countries the elasticity seems to be smaller; see, for example, the discussions in Deardorff and Stern (1990) and Whalley (1985, ch 4). We use $\sigma=1.5$ as our starting point, but experiment with other values as well. We determine $\omega_{1}$ and $\omega_{2}$ from observed ratios of imports and exports to GDP using the first-order condition

$$
p=\left(\omega_{1} / \omega_{2}\right)\left(a_{1} / b_{1}\right)^{1 / \sigma}
$$

In a symmetric steady state with $y_{1}=y_{2}, b_{1}=a_{2}$, and $p=1$, the ratio $a_{1} / b_{1}$ can be expressed as $\left(1-b_{1} / y_{1}\right) /\left(b_{1} / y_{1}\right)$, where $b_{1} / y_{1}$ is the ratio is imports to GNP in country 1 . With $p=1$, this determines the ratio $\omega_{1} / \omega_{2}$. We set the levels of $\omega_{1}$ and $\omega_{2}$ so that the steady state value of $y_{1}$ is one. We use an 
import share of 0.15 , which is approximately its average value in the United States, Japan, and Europe (in aggregate) over the last decade. We postpone discussion of government spending shocks until they are used in the next section.

These parameter values are listed in Table 3. We use them as a benchmark, but also consider a number of alternative values.

\section{Properties of the Theoretical Economy}

We can now compute equilibrium time paths for variables in our theoretical economy and compare them to the properties of aggregate data that we reviewed earlier. We do this for the benchmark parameter values, described in the previous section, and also for some other values. This sensitivity analysis provides an assessment of the importance of various parameters in generating specific properties of the theoretical economy and some feeling for the robustness of these properties: It also provides some intuition for the model's behavior.

Our objective is to document the theoretical relation between net exports and the terms of trade and to determine, in particular, whether the theory produces a J-curve. We find it useful to start, however, with some summary statistics. These statistics shed light on aspects of the model that play a role in the dynamics of net exports and the terms of trade, and may also have some independent interest. Thus we report, in Table 4, the same properties of the theoretical economy that we documented for developed countries in Table 1. The first row, which we refer to as the benchmark economy, uses the parameter values specified in the last section and listed in Table 3. We find, first, that both net exports and the terms of trade are highly autocorrelated. The autocorrelation of net exports is somewhat less than we see in U.S. data (0.61 in the model v. 0.74 in the data), but is 
within the range observed for other countries. The autocorrelation of the terms of trade in the model $(0.83)$ is very close to its median value in the data (0.80). In one respect neither of these properties is surprising: the variables of the model inherit to a large extent the high degree of persistence in the shocks to technology.

We turn next to correlations between net exports and other variables. In the benchmark economy net exports is countercyclical: its contemporaneous correlation with output is -0.64 . This characteristic is stronger than we see in U.S. data, but is within the range of variation observed across the eleven countries of our sample. These countercyclical movements in the trade balance illustrate a feature of our economy that plays a central role in trade/price comovements as well: they indicate that fluctuations in the trade balance are closely tied to fluctuations in investment. The trade balance and investment are connected, as we know, by an identity: net exports is the difference between the values of national output and absorption, the sum of consumption, investment, and government purchases. Countercyclical movements in net exports mean, then, that absorption varies more over the cycle than output. We can narrow this variability further to its components. In this economy, government spending, $g$, is fixed at zero by assumption, and the desire of consumers for smooth consumption streams leads to a standard deviation of consumption less than half that of output. Thus output net of consumption and government purchases is procyclical. The countercyclical movements of trade are the result, then, of strong procyclical movements in investment. In the model, as in the data, these fluctuations are large enough to make absorption more variable over the cycle than output and lead to a negative correlation between net exports and output.

Returning to Table 4, we see a strong inverse relation between net 
exports and the terms of trade: the trade balance is generally positive when the relative price of foreign goods is low. This correlation is generally negative in the data, too, with the United States as a notable exception. We also find that the correlation between the terms of trade and output is strongly positive in the theoretical economy; in the data, there is no obvious regularity.

More interesting, for our purposes, is the cross-correlation function for net exports and the terms of trade. We see, in Figure 2, that the crosscorrelation function has the characteristic asymmetric shape that we've labeled the $\mathrm{J}$-curve, so in that sense the theory delivers one of the striking features of the data. We can get some intuition for the behavior underlying this correlation from the dynamic response functions pictured in Figure 3, where we graph the dynamic responses of the terms of trade and other variables to a one-time shock to domestic productivity. On impact we see an increase in domestic output and thus a decrease in its relative price, the inverse of the terms of trade. In the second panel of the figure we see that this shock also raises consumption, but by less than half the increase in output. Investment, on the other hand, rises much more than consumption and drives the trade balance into deficit. Thus the contemporaneous correlation between net exports and the terms of trade is negative. As time passes the investment boom dissipates and the trade balance moves into surplus, producing a positive correlation between net exports and lagged movements in the terms of trade. Thus investment plays a central role in the dynamics of the trade balance with respect to both output and the terms of trade. We see, in short, that the theory produces a J-curve and that the dynamics of net exports and the terms of trade can be understood as a consequence of the influence of capital formation on the balance of trade.

The remaining experiments of Table 4 illustrate both the sensitivity of 
these properties to values of particular parameters and the possible role of additional shocks. The former provides an indication of the robustness of the model economy's properties and some clues to its functioning. The latter provides an indication of whether the relation between the trade balance and the terms of trade is invariant to the source of movements in each.

Perhaps the most important parameter for the trade-balance/terms-oftrade relation is the elasticity of substitution between foreign and domestic goods. In the benchmark economy this elasticity is 1.5; in the next two experiments we choose larger and smaller values. These changes have a notable effect on the contemporaneous correlation between net exports and the terms of trade. In the large elasticity experiment $(\sigma=2.5)$ the correlation is weaker, moving from -0.41 in the benchmark case to -0.05 . In the small elasticity experiment $(\sigma=0.5)$ the correlation is more strongly negative. Evidently the elasticity parameter $\sigma$ has a strong influence on this correlation. In Figure 4 we describe how the correlation varies with $\sigma$. The point where the correlation changes from negative to positive occurs at about $\sigma=2.7$. The role of this elasticity in determining the sign of the trade/price correlation is reminiscent of the analysis of Marshall, Lerner, and Robinson, who emphasized a somewhat different elasticity.

Our impression of the effect of the elasticity of substitution on trade dynamics is somewhat different if we examine noncontemporaneous trade/price correlations, In Figure 5 we report cross-correlation functions for net exports and the terms of trade for each of the first three theoretical economies, in the same format as Figure 1. We find that for each of the three values of the substitution elasticity, the cross-correlation function has what we term a $\mathrm{J}$-curve, with the correlations increasing initially as we move to the right. What the elasticity does is shift this curve up and down: as we increase $\sigma$ the cross-correlation function shifts up and the point at 
which it changes sign shifts to the left. Thus the elasticity changes the contemporaneous correlation between the trade balance and the terms of trade, but does not alter its characteristic shape.

This dependence of the timing of the J-curve on the elasticity of substitution suggests a more subtle interpretation of the data: that there is a relation between the timing of the trough in the cross-correlation function and the elasticity of substitution. Studies that estimate the elasticity of substitution between foreign and domestic goods typically find larger values for the U.S. than for Europe and Japan; see Whalley's (1985, ch 4) survey of the evidence. We also see that the J-curve for the U.S. in Figure 1 is shifted to the left relative to those for other countries. Perhaps further work will tell us how robust the relation between these two properties is.

To this point we have considered experiments in which productivity shocks are the only source of fluctuations. Another" potentially important source of shocks is government purchases, which have been emphasized in related contexts by Hodrick (1988), Obstfeld (1989), and Yi (1991). In our next experiment, labeled two shocks, we consider a combination of productivity and government spending shocks. Our parameter values in this case are derived from Chari, Christiano, and Kehoe's (1991) estimates for the U.S. The mean value of $g$ in each country is 20 percent of steady state output, which we normalize at one. We set $B=\operatorname{diag}(0.95,0.95)$, so that shocks in each country are highly persistent. The innovations are assigned standard deviations equal to 2 percent of mean government spending, or 0.004 . In most respects, this experiment is similar to the benchmark economy, in which there are no shocks to government purchases. We see in Figure 6 that the cross-correlation function between net exports and the terms of trade is not much different from that of the benchmark economy. 
We have seen, then, that our theoretical economy generates the asymmetric pattern of cross-correlations between net exports and the terms of trade that we have labeled the J-curve. It appears, however, that the dynamics of the theory are more rapid than those in the data, with the cross-correlation function changing sign one to two quarters faster, with some parameter values, in our theoretical economy than in the data. This suggests, we think, that additional sources of dynamics might help to provide a better account of trade dynamics. Some of these sources have long been a staple of trade theory, ranging from early discussions of the J-curve (Cooper, 1971; Junz and Rhomberg, 1973) to recent work on hysteresis (Dixit, 1989; Baldwin and Krugman, 1990). We consider a longer construction period for capital formation and a one-quarter shipping lag for internationally traded goods. The latter introduces, as well, some subtle measurement issues for the terms of trade.

We consider, first, modifications of the dynamics of capital formation. Most studies posit either adjustment costs or multi-period construction for the technology of investment. Baxter and Crucini (1991) and Mendoza (1991), for example, consider convex costs of changing the capital stock. Kydland and Prescott (1982), on the other hand, argue for time-to-build and suggest that a four-quarter construction period $(\mathrm{J}=4$, in the notation of our theory) is closer to what we see in the U.S. economy. We consider an intermediate experiment with $\mathrm{J}=2$, labeled time-to-build in Table 4 . We find, for this experiment, that the pattern of cross-correlations is not much different from the benchmark economy. As we see in Figure 7, this modification shifts the correlation function to the right about one quarter, bringing the theory closer to what we see in the data for most countries.

A second modification is a one-period lag in the trade process: goods exported from country 1, say, in period $t$ cannot be used in country 2 until 
period $t+1$. We think of this delay as including both transportation time and time needed to clear customs. The Armington aggregators in period $t$, in this case, are $G\left(a_{1 t}, b_{1 t-1}\right)$ and $G\left(a_{1 t-1}, b_{1 t}\right)$ in the two countries. We label this one-period delivery lag time-to-ship.

This shipping lag introduces a subtle measurement issue: it is not clear what concept of price corresponds most closely to that used in constructing import price indexes. One possibility is the "delivery" price, which in our framework would give rise to a terms of trade in country 1 of

$$
\mathrm{p}_{\mathrm{t}}=\left\{\partial \mathrm{G}\left(\mathrm{a}_{1 \mathrm{t}}, \mathrm{b}_{1 \mathrm{t}-1}\right) / \partial \mathrm{b}_{1 \mathrm{t}-1}\right\} /\left\{\partial \mathrm{G}\left(\mathrm{a}_{1 \mathrm{t}}, \mathrm{b}_{1 \mathrm{t}-1}\right) / \partial \mathrm{a}_{1 \mathrm{t}}\right\}
$$

This relative price corresponds to the value of imports once they clear customs. An alternative is the "contract" price prevailing at the time the import goods are ordered. In this case, the equilibrium terms of trade would be

$$
p_{t}=\beta E_{t}\left\{\partial G\left(a_{1 t+1}, b_{1 t}\right) / \partial b_{1 t}\right\} /\left\{\partial G\left(a_{1 t}, b_{1 t-1}\right) / \partial a_{1 t}\right\}
$$

We report properties of the latter in Table 4. It remains, however, an interesting issue for future research.

We find that the delivery lag in time-to-ship has a modest impact on the dynamics of the terms of trade. As we see in Figure 7 , the cross-correlation function is shifted to the right, relative to the benchmark economy, again making it more similar to those in the data for many countries. In this sense, both time-to-build and time-to-ship are useful extensions of the benchmark economy.

We have emphasized the implications of the theory for the correlations between trade and relative prices. Another feature of the model is that the standard deviation of the terms of trade is much smaller than we see in the data. If we compare the standard deviation in the benchmark economy 10.48 in 
Table 4) to U.S. data (2.92 in Table 1), the latter is larger by a factor of about six. The differential is smaller if we use a larger import share or make productivity differentials more persistent, but even in these cases the discrepancy between theory and data is substantial. Some of this difference may, in fact, reflect measurement error in import and export prices, as we noted in Section I. We think it unlikely, however, that the measurement error is large enough to account for the discrepancy between theory and data. The same discrepancy has been noted in a similar context by Stockman and Tesar (1990), who show that it can be reduced by introducing nontraded goods.

\section{Two Extreme Experiments}

We argued in the last section that the dynamics of trade were the result, primarily, of investment dynamics. If this is true, an economy without capital and investment should behave much differently. In the experiment labeled no capital in Table 4, we set the capital share parameter $\theta$ equal to 0.0014 , which effectively eliminates capital from the economy. We find that net exports is now procyclical and that the contemporaneous correlation of net exports and the terms of trade is strongly positive. The cross-correlation function, Figure 8 , is tent-shaped: there is no evidence of the asymmetric shape we call the J-curve. All of these properties result from consumption smoothing. Since consumption is smoother than income, net exports, the difference between the two variables, is procyclical. A favorable shock to domestic productivity leads to an increase in domestic output, a smaller increase in domestic consumption, and a trade surplus. The relative price of domestic goods falls, and the terms of trade rises. This leads to a positive contemporaneous correlation that decays over time.

The critical role played by investment illustrates, in addition, a major difference with a prominent theoretical account of the connection between 
trade and price movements: the 1980s development of the Harberger-LaursenMetzler effect initiated by Obstfeld (1982) and Svensson and Razin (1983). This literature is based on the smoothing of consumption that underlies intertemporal optimization by consumers. This gives rise, in their models, to potential connections between relative price movements and saving which translate, in exchange economies, into relations between prices and trade. We find, instead, that the dynamics of trade are understood more simply as reflections of investment dynamics. Without investment, our theoretical economy does not account for either the $J$-curve or the countercyclical movements in trade.

Another extreme experiment is labeled government shocks, in which shocks to government purchases $g$ serve as the sole impulse. With only government shocks we find, again, that the properties of the model are much different from our benchmark example. The contemporaneous correlation between net exports and the terms of trade, for example, changes from -0.41 in the benchmark economy to 1.00 . The most interesting aspect of these differences concerns the cross-correlation function. With government spending shocks alone, we see in Figure 8 that the correlation between net exports and the terms of trade is tent-shaped: the cross-correlation function is consistently positive, peaks at lag zero, and decays monotonically in both directions. There is no sign of a J-curve. Once more we can get some intuition for the dynamics from the dynamic responses of the economy to a one-time shock, illustrated in Figure 9. The striking difference between government and productivity shocks shows up largely in the response of investment. There is no tendency, as there is with productivity shocks, for an investment boom to follow the shock; we see, in fact, the opposite with these parameter values. This sharp difference between the economy with productivity and government spending shocks illustrates the hazard of 
predicting comovements between the terms of trade and the trade balance without specifying the shock that gives rise to these movements.

In short, the economy produces a J-curve when capital formation is an important part of the propagation mechanism and fluctuations are driven by shocks to productivity. Without capital, or with shocks only to government spending, it does not. In this sense, both capital formation and the source of price and trade fluctuations are critical factors in determining the shape of the cross-correlation function for net exports and the terms of trade.

\section{Concluding Remarks}

We have used a dynamic general equilibrium model to provide a novel explanation for the J-curve and a new perspective on earlier theories of the relation between trade and relative price movements. With respect to the latter, we find, as Marshall, Lerner, and Robinson did, that elasticities play a key role in determining the sign of the contemporaneous correlation between the terms of trade and net exports. We also find, in contrast to much of the work on the Harberger-Laursen-Metzler effect, that for understanding trade dynamics, consumption smoothing is less important than fluctuations in investment. Finally, we show that the relation between the trade balance and the terms of trade depends critically on the source of shocks. In this sense, the general equilibrium perspective, in which price movements arise endogenously, is essential.

We find that our theoretical economy has properties that resemble, in some respects, those of postwar data in eleven OECD countries. These include, in addition to the $\mathrm{J}$-curve and countercyclical trade, highly autocorrelated net exports and terms of trade. But this class of theoretical economies also has some features that differ sharply with what we see in international time series data. One is that the correlation of consumption 
across countries is much larger than that of output; in the data we generally see the reverse. Both the theory and the data are reviewed in Backus, Kehoe, and Kydland (1992). Another feature of the theoretical economy, documented in this paper and in Stockman and Tesar (1990), is that price movements are much smaller, in general, than we see in the data. An issue in the present context is how these anomalous features affect our assessment of other properties of the economy. It is probably impossible to answer that without knowing how those anomalies are resolved. Nevertheless, we think the J-curve property may be fairly robust, since it relies primarily on the persistence of productivity shocks and the dynamics of capital formation, features that may apply to a much broader class of economies than ours. Thus we suspect that this account of the J-curve may survive the changes that are called for by anomalies in other dimensions of the model's properties. 


\section{APPENDIX}

\section{Data Sources and Definitions}

The data the underlie Table 1 were taken from the Organization for Economic Cooperation and Development's Quarterly National Accounts. This data is reported quarterly in a publication of the same name; our numbers come from a machine-readable dataset supported by the Board of Governors of the Federal Reserve System. The variables of interest are

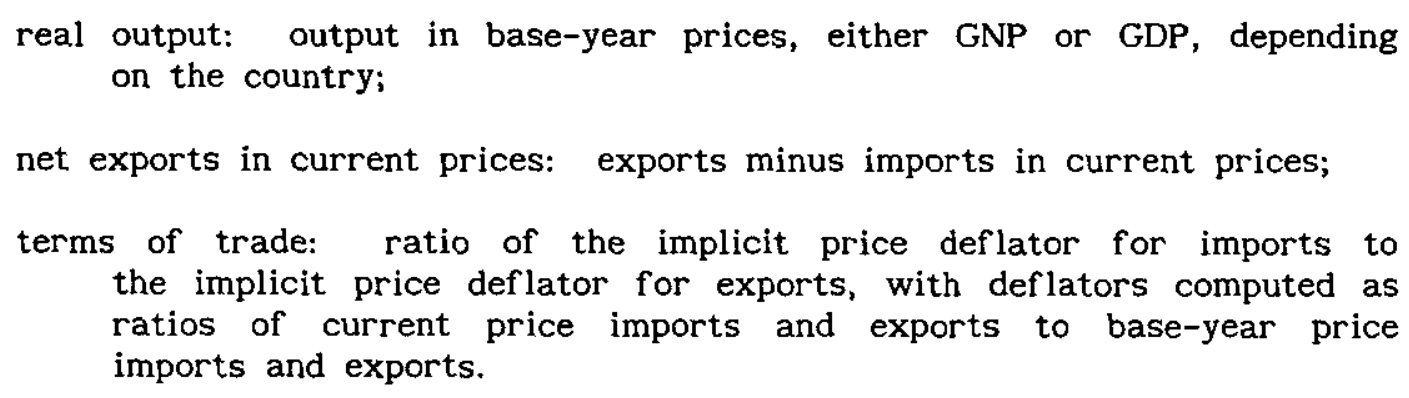

The sample periods noted in Table 1 are the complete samples from the January 1991 version of the database. The data for Australia, Austria, and Finland were seasonally adjusted by us using the $\mathrm{X}-11$ method. 


\section{REFERENCES}

William Alterman, "Price trends in U.S. trade: New data, new insights," unpublished manuscript, presented at the NBER Conference on Income and Wealth, November 1989.

Paul Armington, "A theory of demand for products distinguished by place of production," IMF Staff Papers, 27 (1969), 488-526.

David Backus, Patrick Kehoe, and Finn Kydland, "International real business cycles," Journal of Political Economy, 101 (August 1992), forthcoming.

Richard Baldwin and Paul Krugman, "Persistent trade effects of large exchange rate shocks," Quarterly Journal of Economics, 104 (November 1982), 635-654.

Marianne Baxter and Mario Crucini, "Explaining saving/investment correlations," unpublished manuscript, University of Rochester, May 1991.

V.V. Chari, Lawrence Christiano, and Patrick Kehoe, "Optimal fiscal policy in a business cycle model," unpublished manuscript, Federal Reserve Bank of Minneapolis, September 1991.

Richard Cooper, "An assessment of currency devaluation in developing countries." In G. Ranis, ed., Government and Economic Development, New Haven: Yale University Press, 1971.

Alan Deardorff and Robert Stern, Computational Analysis of. Global Trading Arrangements, Ann Arbor: University of Michigan Press, 1990.

Avinash Dixit, "Entry and exit decisions under fluctuating exchange rates," Journal of Political Economy, 98 (June 1989), 620-638.

Rudiger Dornbusch and Paul Krugman, "Flexible exchange rates in the short run," Brookings Papers on Economic Activity, 3: 1976, 537-575.

Arnold Harberger, "Currency depreciation, income, and the balance of trade," Journal of Political Economy, 58 (1950), 47-60.

Robert Hodrick, "U.S, international capital flows: Perspectives from rational maximizing models," Carnegie-Rochester Conference Series on Public Policy, 30 (Spring 1988), 231-288.

Helen Junz and Rudolf Rhomberg, "Price competitiveness in export trade among industrial countries," American Economic Review, 63 (May 1973), 412-418.

Finn Kydland and Edward Prescott, "Time to build and aggregate fluctuations," Econometrica, 50 (November 1982), 1345-1370.

Svend Laursen and Lloyd Metzler, "Flexible exchange rates and the theory of employment," Review of Economics and Statistics, 32 (1950), 281-299.

Alfred Marshall, Money, Credit, and Commerce, London: Macmillan, 1923. 
Enrique Mendoza, "Real business cycles in a small open economy," American Economic Review, 81 (September 1991), 797-818.

Enrique Mendoza, "Some international evidence on the correlation between the trade balance and the terms of trade," unpublished manuscript, International Monetary Fund, December 1990.

Maurice Obstfeld, "Aggregate spending and the terms of trade: Is there a Laursen-Metzler effect?" Quarterly Journal of Economics, 97 (May 1982), 251-270.

Maurice Obstfeld, "Fiscal deficits and relative prices in a growing economy," Journal of Monetary Economics, 23 (May 1989), 461-484.

Andrew Rose and Janet Yellen, "Is there a J-curve?" Journal of Monetary Economics, 24 (July 1989), 53-68.

Alan Stockman and Lars Svensson, "Capital flows, investment, and exchange rates," Journal of Monetary Economics, 19 (1987), 171-201.

Alan Stockman and Linda Tesar, "Tastes and technology in a two-country model of the business cycle: Explaining international comovements," unpublished manuscript, November 1990.

Lars Svensson and Assaf Razin, "The terms of trade and the current account: The Harberger-Laursen-Metzler effect," Journal of Political Economy, 91 (February 1983), 97-125.

John Whalley, Trade Liberalization Among Major Trading Areas, Cambridge, MA: MIT Press, 1985.

Kei-Mu Yi, "Can government purchases explain recent U.S. net export deficits?" unpublished manuscript, presented at the NBER Universities Conference, May 1991. 
Table 1

Properties of Net Exports, Real Output, and the Terms of Trade

\begin{tabular}{|c|c|c|c|c|c|c|c|c|c|}
\hline \multirow[b]{2}{*}{ Country } & \multicolumn{3}{|c|}{$\begin{array}{c}\text { Std. Deviation } \\
\text { (percent) }\end{array}$} & \multicolumn{3}{|c|}{ Autocorrelation } & \multicolumn{3}{|c|}{ Correlation } \\
\hline & $\mathrm{nx}$ & $\mathbf{y}$ & $\mathrm{p}$ & $\mathrm{nx}$ & $\mathbf{y}$ & p & $(\mathrm{nx}, \mathrm{y})$ & $(n x, p)$ & $(y, p)$ \\
\hline Australia & 1.36 & 1.53 & 5.25 & .74 & .65 & .82 & -.19 & -.09 & -.27 \\
\hline Austria & 1.11 & 1.20 & 1.63 & .29 & .60 & .50 & -.44 & -.16 & .13 \\
\hline Canada & .79 & 1.52 & 2.44 & .59 & .76 & .85 & -.42 & .04 & -.10 \\
\hline Finland & 1.75 & 1.62 & 1.96 & .40 & .56 & .73 & -.60 & -.46 & .17 \\
\hline France & .83 & .91 & 3.54 & .71 & .76 & .75 & -.29 & -.50 & -.12 \\
\hline Germany & .80 & 1.50 & 2.64 & .60 & .69 & .86 & -.17 & .00 & -.13 \\
\hline Italy & 1.34 & 1.69 & 3.52 & .80 & .85 & .79 & -.68 & -.66 & .38 \\
\hline Japan & 1.01 & 1.68 & 5.86 & .81 & .74 & .88 & -.18 & -.47 & -.12 \\
\hline Switzerland & 1.33 & 1.93 & 2.92 & .90 & .90 & .88 & -.68 & -.61 & .40 \\
\hline U.K. & 1.06 & 1.47 & 2.66 & .67 & .56 & .75 & -.23 & -.54 & .19 \\
\hline U.S. & .45 & 1.83 & 2.92 & .80 & .82 & .80 & -.22 & .27 & .03 \\
\hline Median & 1.06 & 1.53 & 2.92 & .71 & .74 & .80 & -.29 & -.46 & .03 \\
\hline
\end{tabular}

Notes: Data are quarterly, from the OECD's Quarterly National Accounts. The variables are: the ratio of net exports to output (nx), the logarithm of real output $(y)$, and the logarithm of the ratio of the import deflator to the export deflator (p). All statistics refer to Hodrick-Prescott filtered variables. Sample periods are: Australia, 1960:1-1990:1; Austria, 1964:1-1990:1; Canada, 1955:1-1990:1; Finland, 1975:1-1990:1; France, 1970:1-1990:1; Germany, 1968:1-1990:1; Italy, 1970:1-1990:1; Japan, 1955:2-1990:1; Switzerland, 1970:1-1990:1; United Kingdom, 1955:1-1990;1; United States, 1950:1-1990:2. 
Table 2

The Trade Balance and the Terms of Trade: Cross-Correlation Functions

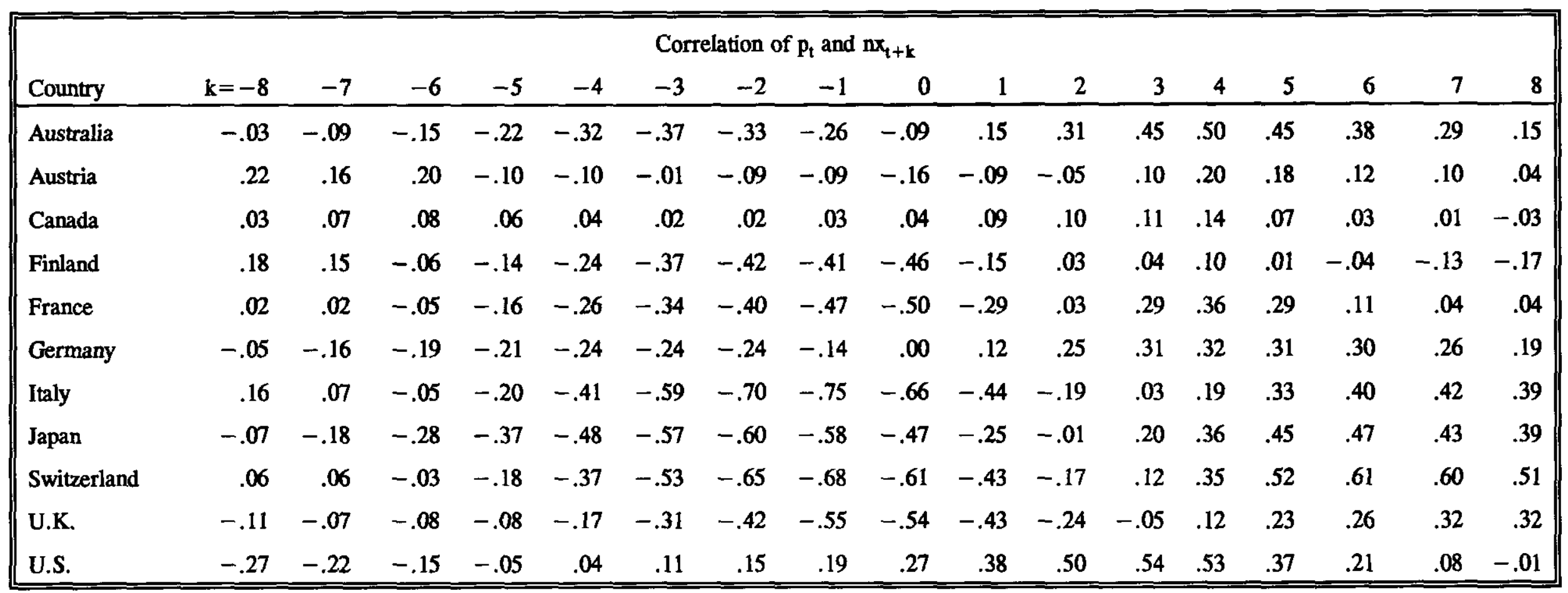

Notes: See the notes to Table 1. 
Table 3

Benchmark Parameter Values

\begin{tabular}{|ll||}
\hline Preferences & $\beta=.99, \mu=.34, \gamma=-1.0$ \\
Technology & $\theta=.36, \delta=.025, \mathrm{~J}=1$, \\
& $\sigma=1 /(1+\rho)=1.5$, import share $=.15$ \\
Forcing processes & $\mathrm{A}=\left[\begin{array}{ll}\mathrm{a}_{11} & \mathrm{a}_{12} \\
\mathrm{a}_{12} & \mathrm{a}_{11}\end{array}\right]=\left[\begin{array}{ll}.906 & .088 \\
.088 & .906\end{array}\right]$ \\
& $\mathrm{var} \epsilon_{1}^{\mathrm{z}}=\operatorname{var} \epsilon_{2}^{\mathrm{z}}=.00852^{2}, \operatorname{corr}\left(\epsilon_{1}^{\mathrm{z}}, \epsilon_{2}^{\mathrm{z}}\right)=.258$ \\
& $\mathrm{~g}_{\mathrm{t}}=0$.
\end{tabular}


Table 4

Properties of Theoretical Economies

\begin{tabular}{|c|c|c|c|c|c|c|c|c|c|}
\hline \multirow[b]{2}{*}{ Economy } & \multicolumn{3}{|c|}{$\begin{array}{l}\text { Std. Deviation } \\
\text { (percent) }\end{array}$} & \multicolumn{3}{|c|}{ Autocorrelation } & \multicolumn{3}{|c|}{ Correlation } \\
\hline & $\mathrm{nx}$ & y & p & $\mathrm{nx}$ & $\mathbf{y}$ & $\mathbf{p}$ & $(\mathrm{nx}, \mathrm{y})$ & $(n x, p)$ & $(y, p)$ \\
\hline Benchmark & $\begin{array}{l}.30 \\
(.02)\end{array}$ & $\begin{array}{l}1.38 \\
(.18)\end{array}$ & $\begin{array}{l}.48 \\
(.06)\end{array}$ & $\begin{array}{l}.61 \\
(.07)\end{array}$ & $\begin{array}{l}.63 \\
(.10)\end{array}$ & $\begin{array}{l}.83 \\
(.05)\end{array}$ & $\begin{array}{c}-.64 \\
(.07)\end{array}$ & $\begin{array}{c}-.41 \\
(.08)\end{array}$ & $\begin{array}{c}.49 \\
(.14)\end{array}$ \\
\hline $\begin{array}{l}\text { Large } \\
\text { Elasticity }\end{array}$ & $\begin{array}{c}.33 \\
(.03)\end{array}$ & $\begin{array}{l}1.41 \\
(.18)\end{array}$ & $\begin{array}{l}.35 \\
(.05)\end{array}$ & $\begin{array}{c}.63 \\
(.07)\end{array}$ & $\begin{array}{c}.64 \\
(.18)\end{array}$ & $\begin{array}{l}.88 \\
(.03)\end{array}$ & $\begin{array}{c}-.57 \\
(.08)\end{array}$ & $\begin{array}{c}-.05 \\
(.09)\end{array}$ & $\begin{array}{c}.43 \\
(.14)\end{array}$ \\
\hline Small Elasticity & $\begin{array}{l}.37 \\
(.03)\end{array}$ & $\begin{array}{l}1.33 \\
(.18)\end{array}$ & $\begin{array}{l}.76 \\
(.07)\end{array}$ & $\begin{array}{l}.61 \\
(.07)\end{array}$ & $\begin{array}{c}.63 \\
(.10)\end{array}$ & $\begin{array}{l}.77 \\
(.05)\end{array}$ & $\begin{array}{r}-.66 \\
(.07)\end{array}$ & $\begin{array}{c}-.80 \\
(.09)\end{array}$ & $\begin{array}{l}.51 \\
(.16)\end{array}$ \\
\hline Two Shocks & $\begin{array}{l}.33 \\
(.03)\end{array}$ & $\begin{array}{l}1.33 \\
(.15)\end{array}$ & $\begin{array}{l}.57 \\
(.07)\end{array}$ & $\begin{array}{l}.62 \\
(.08)\end{array}$ & $\begin{array}{l}.65 \\
(.08)\end{array}$ & $\begin{array}{l}.78 \\
(.06)\end{array}$ & $\begin{array}{c}-.57 \\
(.15)\end{array}$ & $\begin{array}{c}-.05 \\
(.17)\end{array}$ & $\begin{array}{l}.39 \\
(.17)\end{array}$ \\
\hline Time-to-Build & $\begin{array}{l}.28 \\
(.02)\end{array}$ & $\begin{array}{l}1.34 \\
(.17)\end{array}$ & $\begin{array}{l}.51 \\
(.06)\end{array}$ & $\begin{array}{l}.60 \\
(.17)\end{array}$ & $\begin{array}{c}.63 \\
(.10)\end{array}$ & $\begin{array}{l}.52 \\
(.16)\end{array}$ & $\begin{array}{c}-.61 \\
(.07)\end{array}$ & $\begin{array}{c}-.40 \\
(.08)\end{array}$ & $\begin{array}{l}.50 \\
(.12)\end{array}$ \\
\hline Time-to-Ship & $\begin{array}{l}.24 \\
(.02)\end{array}$ & $\begin{array}{l}1.35 \\
(.18)\end{array}$ & $\begin{array}{l}.48 \\
(.05)\end{array}$ & $\begin{array}{l}.65 \\
(.07)\end{array}$ & $\begin{array}{l}.66 \\
(.08)\end{array}$ & $\begin{array}{l}.66 \\
(.09)\end{array}$ & $\begin{array}{c}-.56 \\
(.08)\end{array}$ & $\begin{array}{c}-.51 \\
(.09)\end{array}$ & $\begin{array}{c}.61 \\
(.11)\end{array}$ \\
\hline No Capital & $\begin{array}{l}.18 \\
(.01)\end{array}$ & $\begin{array}{l}1.14 \\
(.15)\end{array}$ & $\begin{array}{l}1.29 \\
(.09)\end{array}$ & $\begin{array}{l}.71 \\
(.06)\end{array}$ & $\begin{array}{c}.61 \\
(.11)\end{array}$ & $\begin{array}{c}.64 \\
(.07)\end{array}$ & $\begin{array}{l}.66 \\
(.06)\end{array}$ & $\begin{array}{l}.99 \\
(.00)\end{array}$ & $\begin{array}{l}.68 \\
(.06)\end{array}$ \\
\hline $\begin{array}{l}\text { Government } \\
\text { Shocks }\end{array}$ & $\begin{array}{l}.16 \\
(.03)\end{array}$ & $\begin{array}{l}.17 \\
(.02)\end{array}$ & $\begin{array}{c}.30 \\
(.05)\end{array}$ & $\begin{array}{c}.67 \\
(.11)\end{array}$ & $\begin{array}{c}.67 \\
(.08)\end{array}$ & $\begin{array}{c}.67 \\
(.11)\end{array}$ & $\begin{array}{c}-.55 \\
(.13)\end{array}$ & $\begin{array}{l}1.00 \\
(.00)\end{array}$ & $\begin{array}{r}-.55 \\
(.13)\end{array}$ \\
\hline
\end{tabular}

Notes: Statistics are based on Hodrick-Perscott (1980) filtered data. Entries are averages over 50 simulations of 100 quarters each; numbers in parentheses are standard deviations. Parameters as in Table 3, except: large elasticity, $\sigma=2.5$; small elasticity, $\sigma=0.5$; two shocks, mean of $\mathrm{g}=\operatorname{diag}(.2, .2)$, B $=\operatorname{diag}(.95, .95)$ and $\mathrm{V}_{\mathrm{g}}=\operatorname{diag}\left(.004^{2}, .004^{2}\right)$; government shocks, as in two shocks plus $\mathrm{z}_{\mathrm{t}}=1$, all t; time to build, $\mathrm{J}=2$; no capital, $\theta=0$; and time to ship, one-period shipping lag, as described in the text. 
Figure 1: Correlations of $\mathrm{p}_{t}$ and $n x_{t+k}$
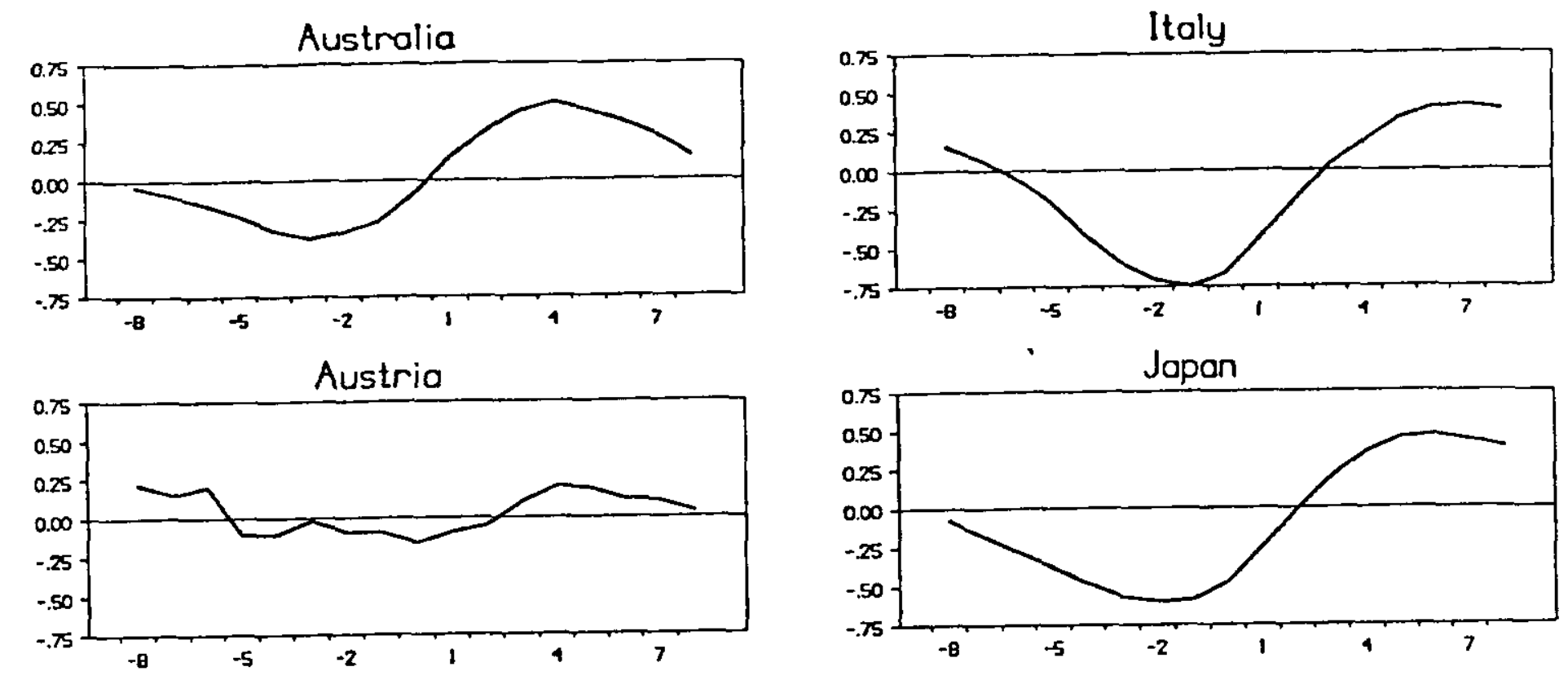

Canada
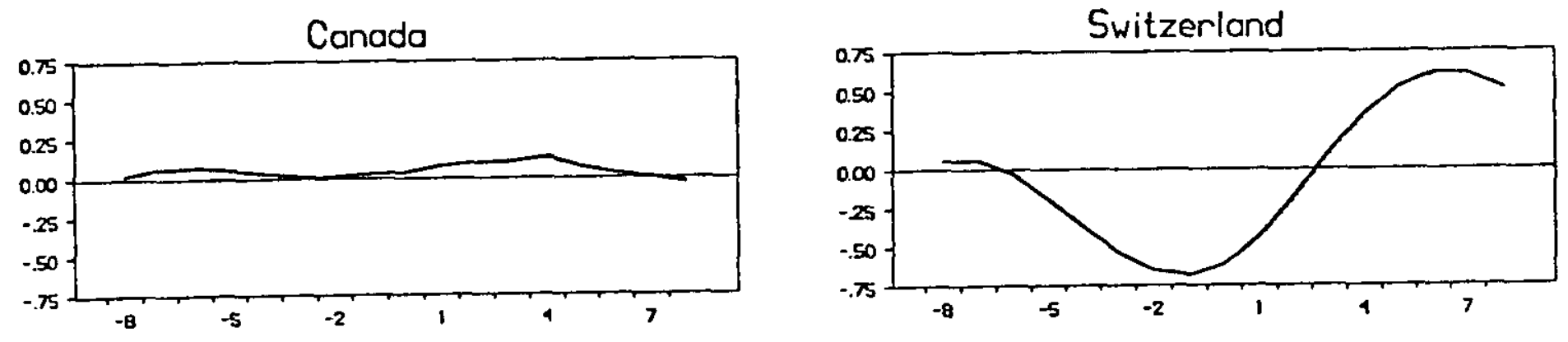

Finland

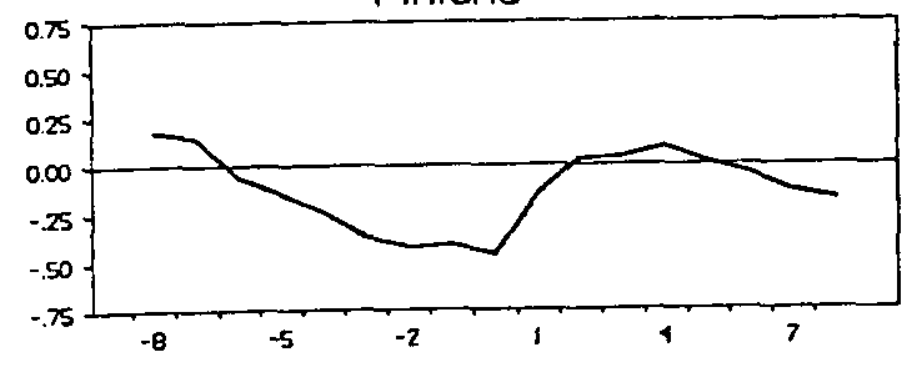

France
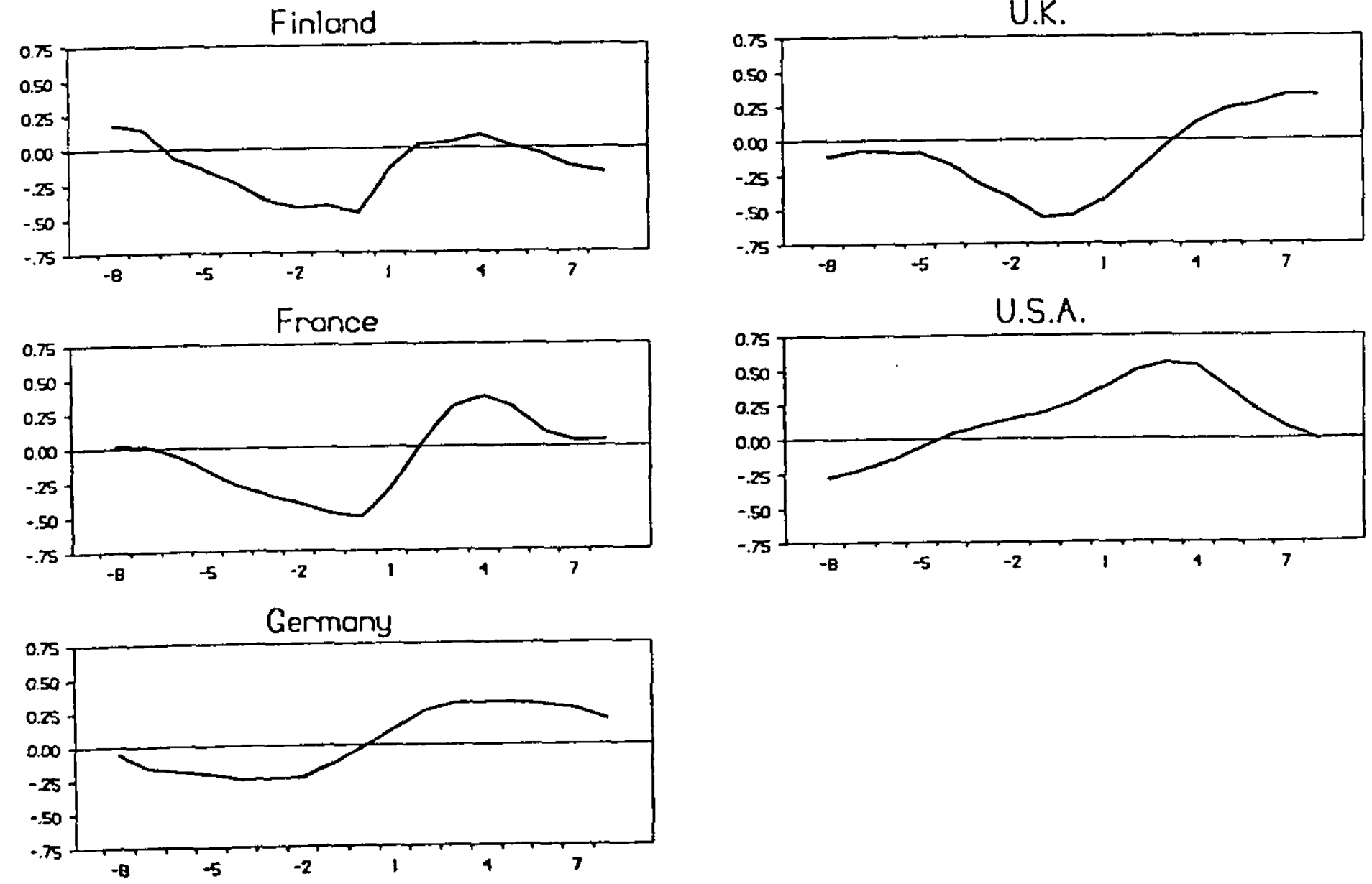
Figure 2

Cross-Correlation Function for the Benchmark Economy

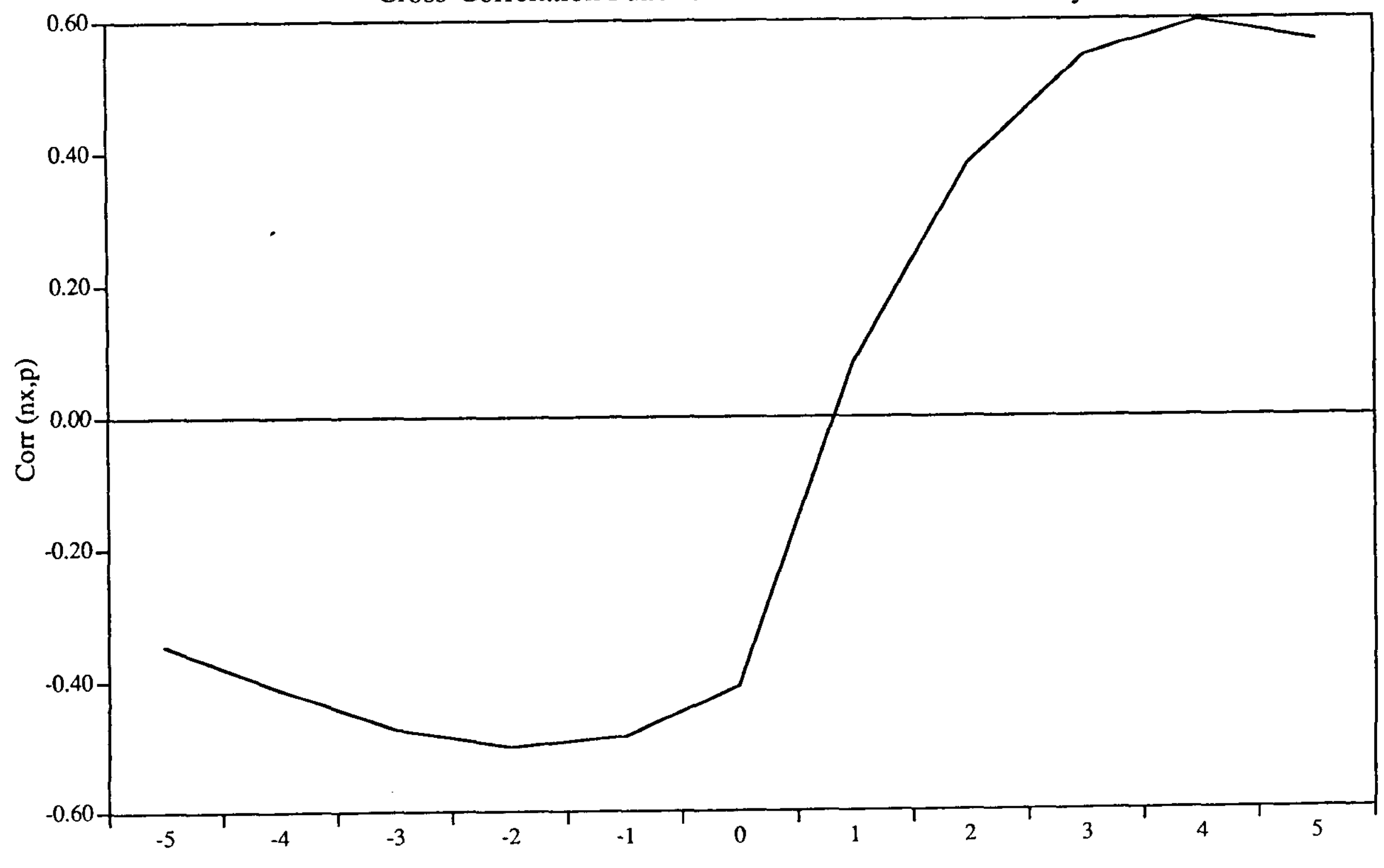


Figure 3
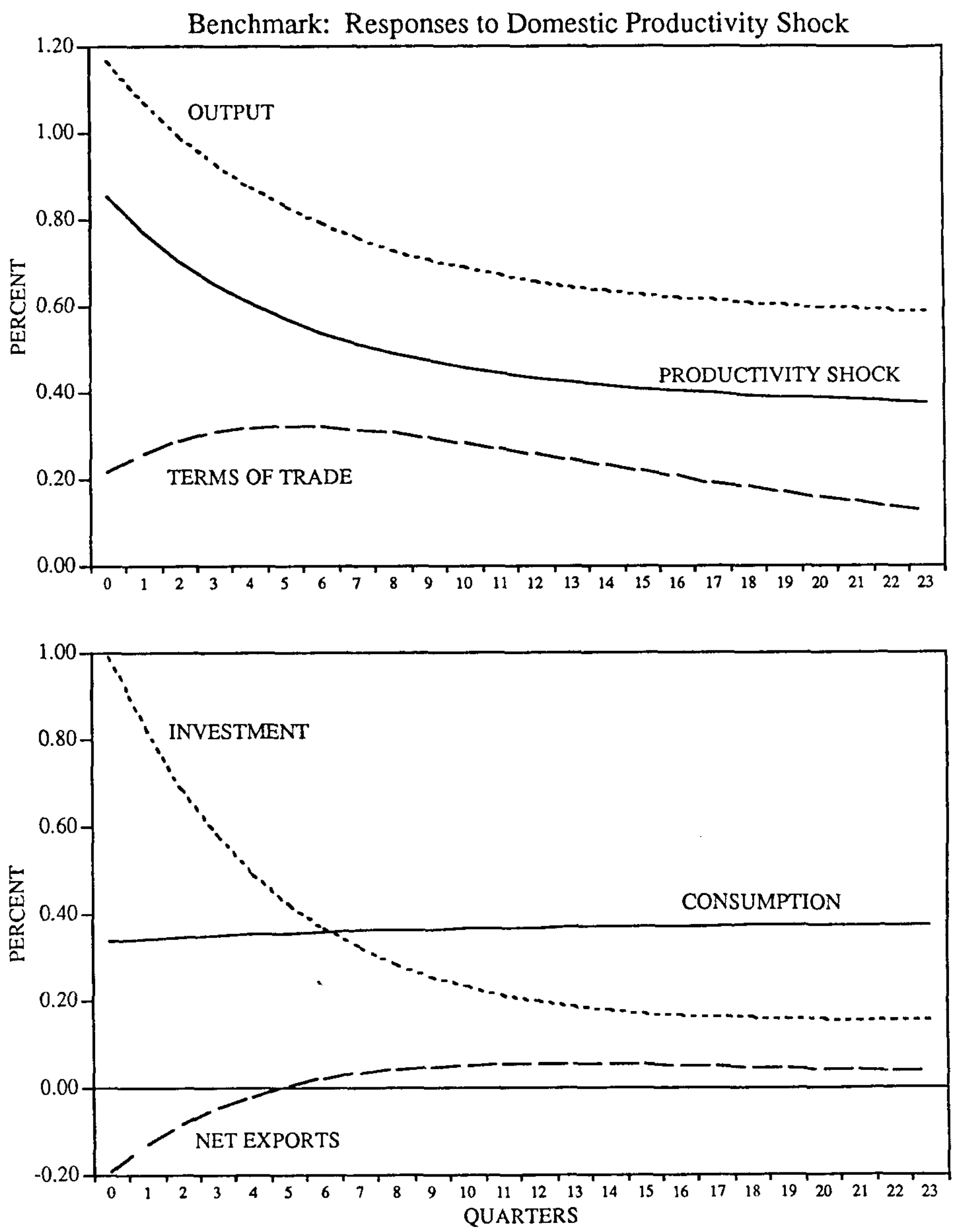
Figure 4

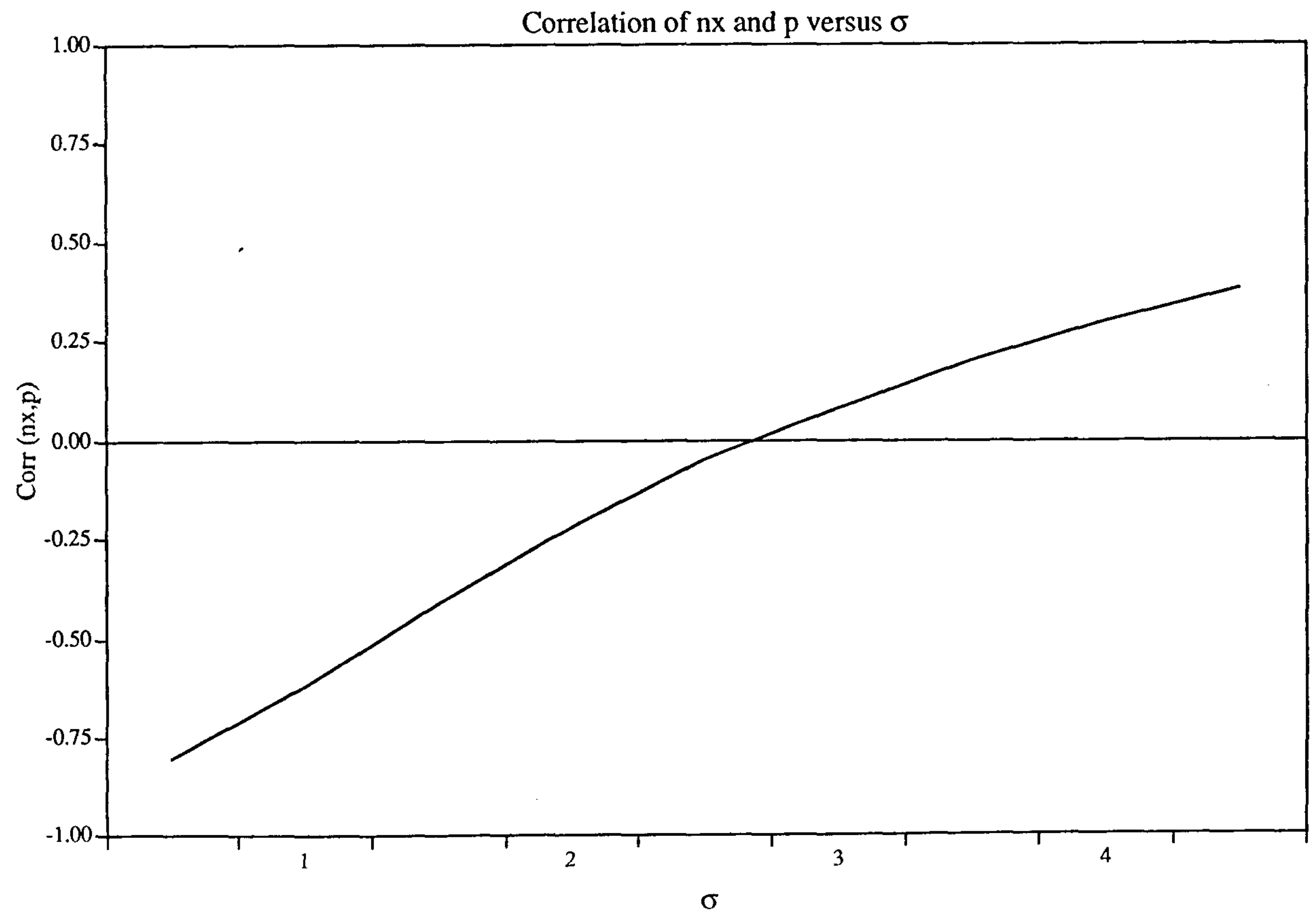


Figure 5

Cross-Correlation Functions with Different Elasticities

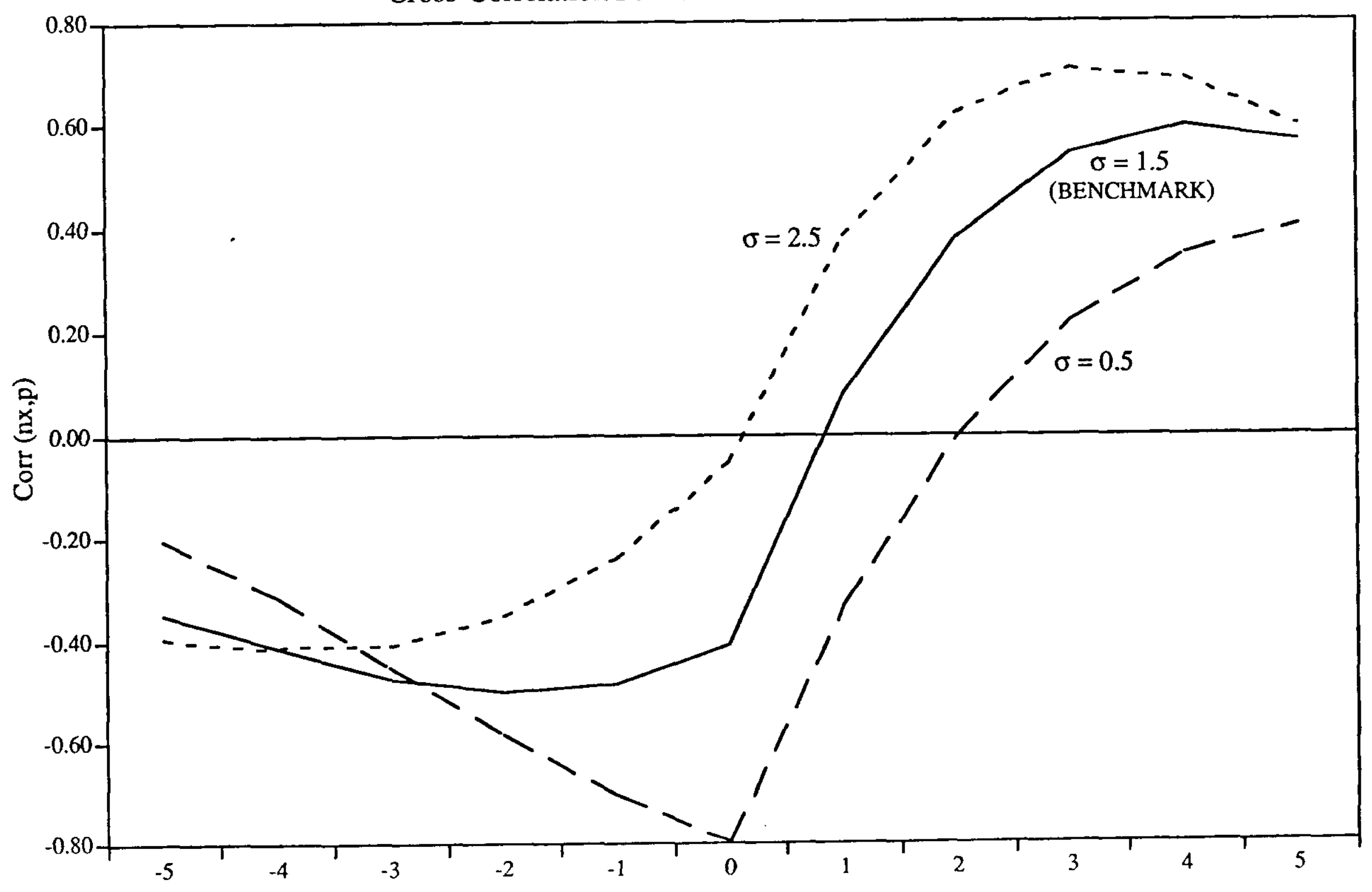


Figure 6

Cross-Correlation Functions with Two Shocks

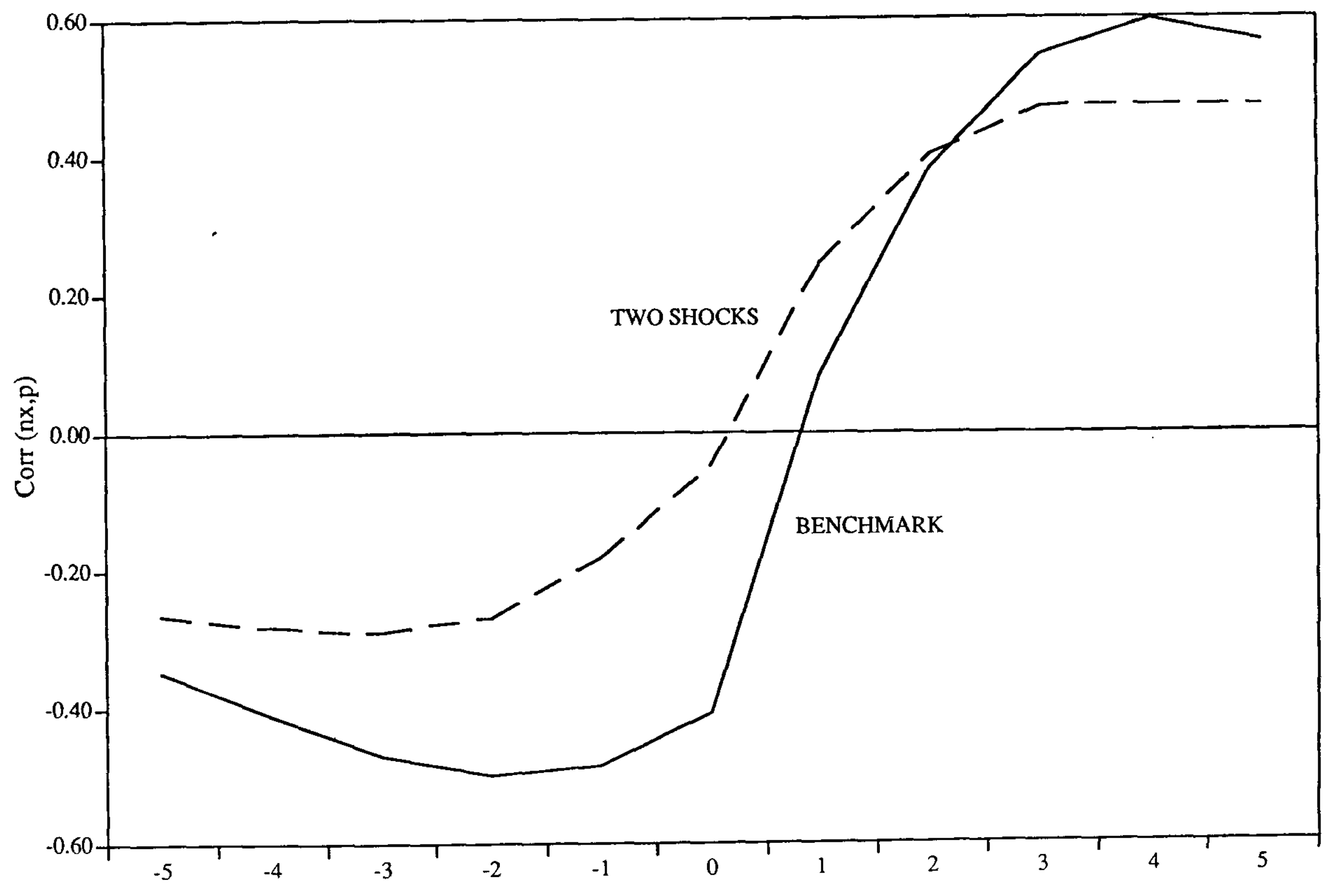


Figure 7

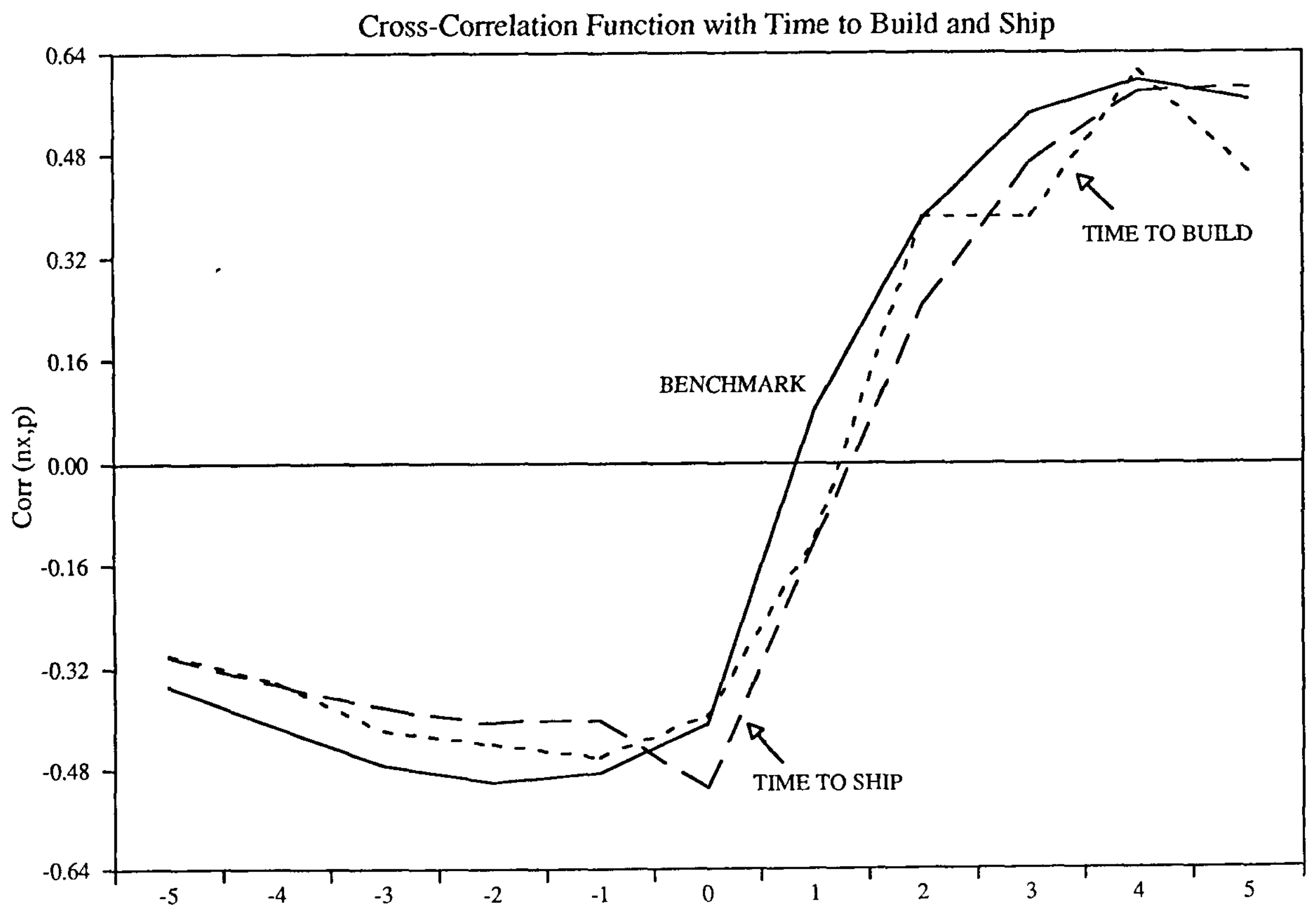


Figure 8

Cross-Correlation Function for Extreme Experiments

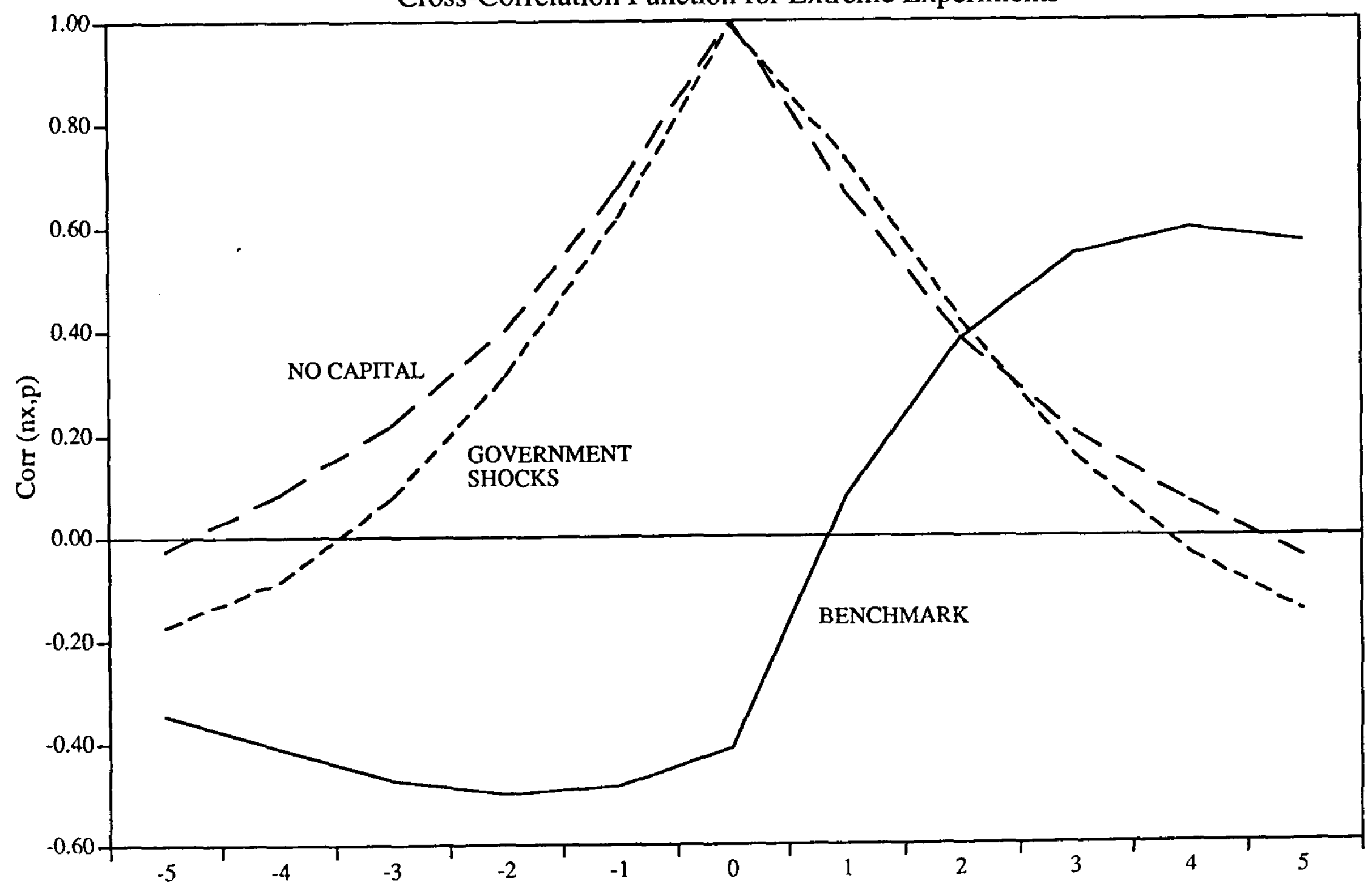


Figure 9
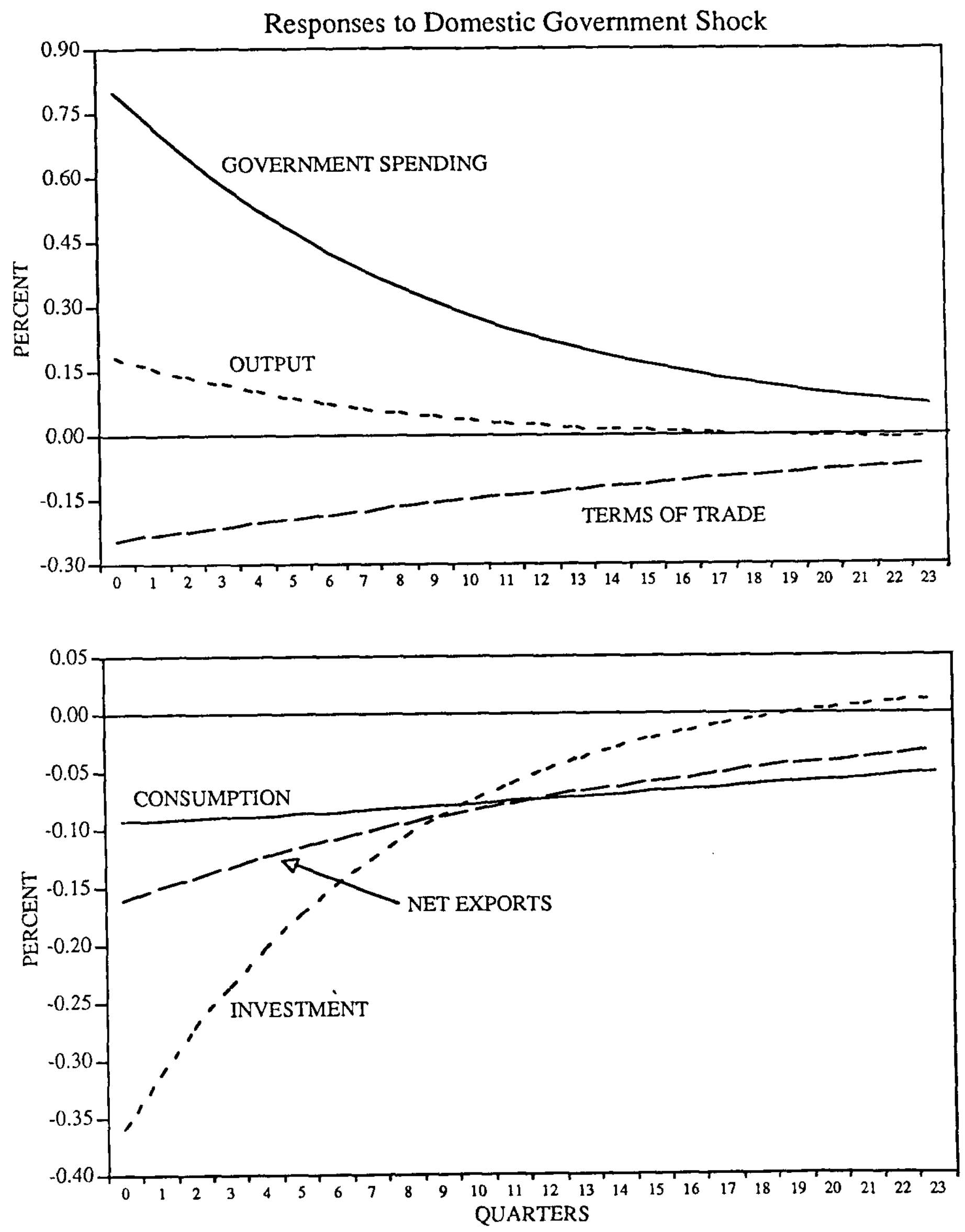